\title{
Sanitation and Diarrheal Morbidity: Evidence from Afghanistan
}

\author{
Manzoor Ahmad Malik', Saddaf Naaz Akhtar ${ }^{2, *}$
}

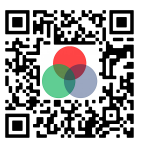

Use your smartphone to scan this QR code and download this article

\begin{abstract}
Background: Lack of sanitation facilities and inadequate water is key to many diseases' outcomes, mainly diarrhea. These factors affect the health status of a country and result in increased mortality and morbidity pattern, particularly among the vulnerable population like children and women. Thus, the study assesses the linkages between diarrheal diseases and sanitation in Afghanistan affected since long by political instability, which has derailed the country's health system. Methods: We used the 2015 Afghanistan Demographic and Health Survey to assess the linkages between sanitation and diarrheal diseases among under-five children. Bivariate and multivariate analyses have been used to carry out the study. The logistic model was used to evaluate the risk factors that lead to diarrheal outcomes. Results: Our findings from the results showed that the prevalence of diarrhea among under-five children in Afghanistan was 29\%. Pashai is the most affected, with 36\% among ethnicities, whereas eastern Afghanistan is the most affected region with a prevalence of (38\%). Open defecated Population (OR: 1.17, p<0.001), Tap water (OR: 1.31, p<0.001), Well water (OR: $1.24, \mathrm{p}<0.001)$, and Sharing toilet (OR: 1.15, $\mathrm{p}<0.001$ ) are significantly associated with childhood diarrhea. Conclusions: A significant impact has been found with inadequate sanitation, shared toilet facility, clean water, and other elements with childhood diarrhea in Afghanistan. The region-wise difference has also been found to be very high across the regions. Thus, it has been found that a lack of such factors has a more significant impact on children's health and needs a particular focus from a policy purpose.

Key words: Sanitation, Diarrhea, Afghanistan, Morbidity, Child health
\end{abstract}

${ }^{1}$ Department of Humanities and social sciences, Indian Institute of Technology (IIT), Roorkee, India

${ }^{2}$ Centre for the Study of Regional Development, School of Social Sciences-III, Jawaharlal Nehru University, New Delhi, India

\section{Correspondence}

Saddaf Naaz Akhtar, Centre for the Study of Regional Development, School of Social Sciences-III, Jawaharlal Nehru University, New Delhi, India

Email: sadafdpsjsr@gmail.com; saddaf54_ssf@jnu.ac.in

History

- Received: 2020-10-12

- Accepted: 2020-11-04

- Published: 2020-11-29

DOI : 10.15419/ajhs.v6i2.479

\section{Check for updates}

\section{Copyright}

(c) Biomedpress. This is an openaccess article distributed under the terms of the Creative Commons Attribution 4.0 International license.

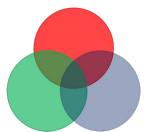

The Open Access Publisher

\section{INTRODUCTION}

Morbidity patterns resulting from pneumonia, diarrhea, fever, and acute respiratory infection are vital in increasing the risk of mortality among under-five children $^{1,2}$. Diarrheal diseases constitute a significant problem among under-five children worldwide after pneumonia $^{3,4}$. Children in the developing world are positively affected by diarrheal diseases, which can be preventable and eradicated by possible interventions ${ }^{5,6}$. Previous studies have shown that children in developing countries are ten times more likely to die before five years than children in the developing world $^{7,8}$. Empirical studies reflect this fact that onefourth of these deaths among children result in south Asia among the under-five children, and Afghanistan is one of the most affected countries in the region ${ }^{9-13}$. According to the 2015 Afghanistan Demographic and Health Survey (AfDHS) report, around one in every 18 children die before completing the age five in Afghanistan, and these deaths mostly occur in the very first year of birth among children ${ }^{14}$. The risk factors to these deaths are manifold and result from both demand and supply-side factors. Other things include the lack of spending in the health care system and socio-behavioral and contextual factors.
Diarrhea is the second leading cause of deaths, accounting for nearly one in every nine deaths worldwide $^{15}$. It is one of the largest reasons for the disease burden in Afghanistan after pneumonia ${ }^{16}$.

The above figure Figure 1 shows the percentage of deaths due to diarrhea in Afghanistan since 2000 based on UNICEF data, and the results show that although there is a decline in diarrheal deaths, it still accounts for nearly $9 \%$ of deaths. A recent survey of 2015 AfDHS showed that around $29 \%$ of children have an acute diarrheal disease in Afghanistan. Therefore, the present study explores the possible factors that affect the greater prevalence of diarrhea among under-five children based on the recent round of 2015 AfDHS.

\section{THEORETICAL CONTEXT}

According to UNICEF, around 2.4 billion people lack adequate sanitation facilities globally, and approximately 663 million people do not have access to improved water ${ }^{5}$. However, the SDG have aimed at improving the conditions of health, particularly of children and women. Nevertheless, these challenges persist and affect a grander scale through morbidity and 


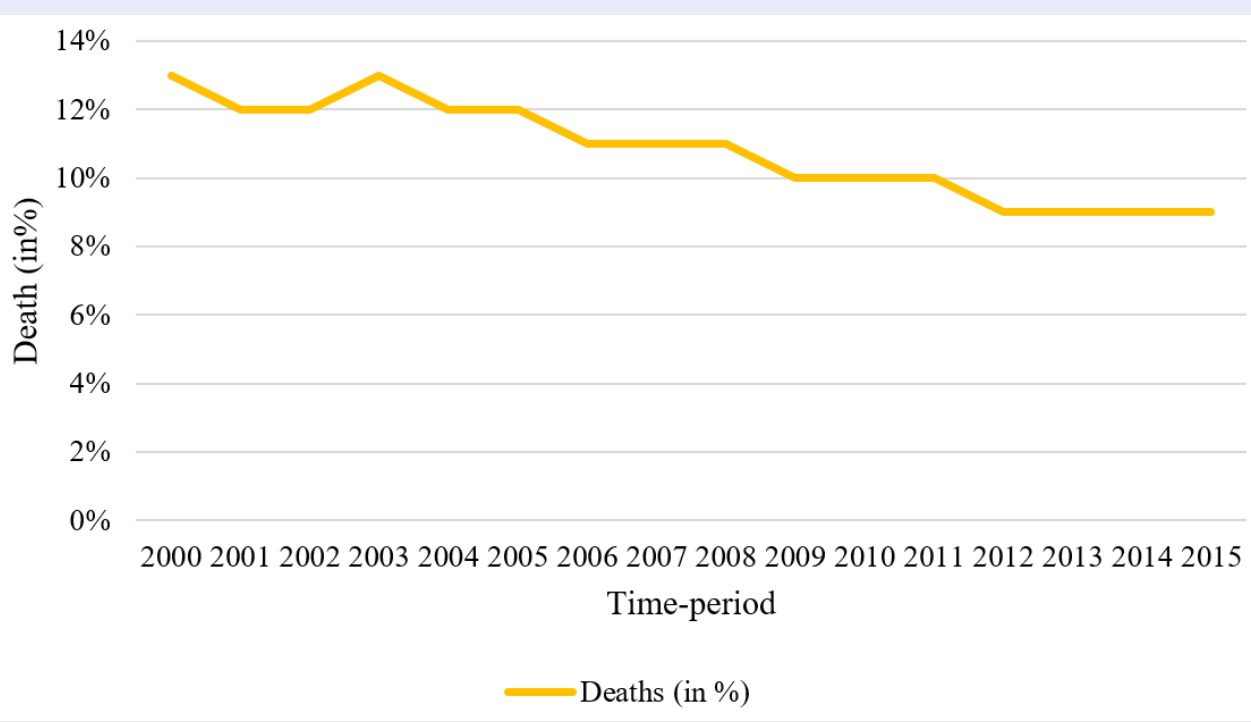

Figure 1: Percentage of deaths due to diarrhea in Afghanistan from 2000-2015. ${ }^{a}$

${ }^{a}$ Source: UNICEF

mortality patterns among under-five children, particularly in developing countries. Children at younger ages are at greater risk of water-borne diseases like diarrhea, affecting their health and well-being and putting them at greater risk. Around 800,000 children die yearly due to conditions resulting from the lack of sanitation facilities cured ${ }^{15}$. Diarrhea has become one of the leading causes of morbidity and mortality among children ${ }^{17}$. Though the diseases have attributed to many factors, some closely associated reasons are inadequate water and lack of sanitation facilities ${ }^{18}$. These factors affect the burden of diarrheal deaths and contribute to a greater prevalence of acute diarrheal diseases ${ }^{19}$. A study has found that socio-demographic factors have played an essential role among Congo children. Other factors, such as open defecation, unhygienic practices, and unimproved water, have shown a significant effect on a child's health ${ }^{20}$. Numerous studies in this context have found that households having inadequate sanitation facilities have a more substantial impact on the incidence of diarrheal outcomes ${ }^{21,22}$. A study ${ }^{23}$ showed that drinking water availability is an essential factor and lack of it results in a greater incidence of childhood diarrheal deaths. A report on Sustainable Development Goals in 2017 also reflected that higher risk for infectious diseases like diarrhea is mainly due to the lack of safe water sanitation and other hygiene services ${ }^{24}$. Increased risk of diarrhea is also due to sanitation facilities' proximity to homes, the sharing of sanitation facilities, and poor hygiene ${ }^{25}$.
Diarrheal deaths account for nearly 1.87 million deaths annually, resulting in numerous factors but primarily due to unsafe water and inadequate sanitation $^{7,9}$. Better sanitation facilities are essential to reduce diarrheal morbidity ${ }^{26}$. Studies clearly show that sanitation infrastructure is most effective, reducing diarrhea incidence by about $20 \%$ while as clean water by $11 \%{ }^{27}$. It has been observed that interventions in providing better access to clean water and toilet facilities lower the risk of diarrhea reduction ranging from $27 \%$ to $53 \%$ among the children aged below five years $^{28}$. Improved sanitation and hygiene are essential to avert the impact of diarrheal deaths ${ }^{29}$. However, a better standard of living conditions can also reduce the burden of diarrhea among under-five children $^{30}$. Thus, targeting the measures that can reduce the levels of inadequate sanitation and lack of access to clean water can lower the morbidity patterns resulting from diarrhea among children aged below five, particularly in a developing world ${ }^{31}$.

Furthermore, hygiene improvement effectively reduces diarrhea and is a critical element of child health and nutritional promotion ${ }^{32-34}$. Though the evidence is strong despite this, there has been little sound evidence published so far on to what extent the availability and utilization of latrines and better water facilities can reduce diarrheal prevalence ${ }^{35,36}$ and the country like Afghanistan has least explored. Therefore, this study tried to examine the linkages between diarrhea and its possible association with sanitation and inadequate water facilities. 


\section{CONCEPTUAL DEFINITIONS}

Diarrhea is defined as the passage of three or more liquid stools within 24 hours ${ }^{26}$. Diarrhea can last for several days, but according to this study, acute diarrhea is the condition where a child suffers from diarrhea for less than 14 days since this leads to severe dehydration and loss of fluids resulting in diarrheal deaths. According to WHO, other causes like septic bacterial infections also account for more diarrheal deaths. Whereas medically, it is defined as a symptom of infection in the intestinal tract, resulting in bacterial, viral, and parasitic organisms were resulting in unimproved water, inadequate sanitation, and poor hygiene.

Sanitation is critical to promote not just human health but also socio-demographic conditions like food security, women empowerment, girl education, social security, and reduction in morbidity and mortality. It just not reduces intestinal and vector-borne diseases but also has a significant impact on diarrhea ${ }^{28}$. In simple words, sanitation means the provision of facilities and services for the safe disposal of human urine and feces. Sanitation refers to the maintenance of hygienic conditions through services such as garbage collection and wastewater disposal. The study uses various measures to measure sanitation access, such as lack of adequate water, toilet facility, access to water, and toilet-sharing facilities.

\section{MATERIAL — METHODS}

The data of the study has taken from Afghanistan Demographic and Health Survey (AfDHS) conducted in 2015-16. AfDHS surveys consist of data on a wide range of public health topics, including anthropometric, demographic, socio-economic, family planning, and domestic violence issues. The AfDHS (201516) provides up-to-date information on the respondents' socio-demographic characteristics between the ages of 15-49 from randomly selected households. AfDHS is a national sample survey that provides upto-date information on fertility levels; marriage; fertility preferences; awareness and use of family planning methods; child feeding practices; nutrition, adult, and childhood mortality; awareness and attitudes regarding HIV/AIDS; women's empowerment; and domestic violence.

\section{STUDY PARTICIPANTS}

The total sample for this analysis was 30303 children aged 0-59 months, who had complete morbidity data and were living with their mothers at the survey time. The AfDHS collected data on morbidity such as diarrhea, which is defined as passing three or more liquid, watery or loose stools per day. The data was collected based on a survey question to mothers, whether any of their children below five years of age had diarrhea during the preceding weeks in the survey.

The outcome variable was the prevalence of diarrhea during the two weeks. This question was asked to Mothers whether or not their child suffered from diarrhea during the past two weeks. The leading independent variables are proxies of indicators like sanitation facility, drinking water, and other socio-demographic variables like age of the child, sex residence, and region.

Bivariate and Multivariate analysis was carried out in the paper to study the association between sanitation and diarrhea. We used a logistic model with a dependent variable categorized into a binary outcome variable as diarrhea and regress it with other closely associated risk factors.

\section{RESULTS}

Figure 2 shows the prevalence of diarrhea by regions. Diarrheal prevalence has found to be higher in the Eastern region (39\%) of Afghanistan, followed by West $(31 \%)$ and North $(30 \%)$ regions. In contrast, lower prevalence is in the Sothern region of Afghanistan (23\%). Here, the prevalence rate has been computed by regions, and the values were significant at one percent level of significance for all the regions.

Figure 3 shows the prevalence of diarrhea by ethnic groups, which has the highest among the Pashai (35\%), followed by Uzbeks (33\%). The lowest prevalence was found to be among the Balochs, which was just $15 \%$. Here, the prevalence rate has been computed by ethnic groups, and the values were significant at one percent level of significance for all the ethnic groups.

Table 1 shows the prevalence of diarrhea and demographic and socio-economic characteristics prevalence of diarrhea is higher among the children aged 612 and 13 to 24 months. Similarly, we see prevalence higher among female children than male children. We found that diarrhea among children was found to be higher among working women. In contrast, children of adolescent mothers have a $2 \%$ higher prevalence of diarrhea than the children of adult mothers. Those households' children who are defecating in the open area are having a higher prevalence of diarrhea. Similarly, the prevalence of diarrhea is also higher among those households' children who are sharing toilets. 


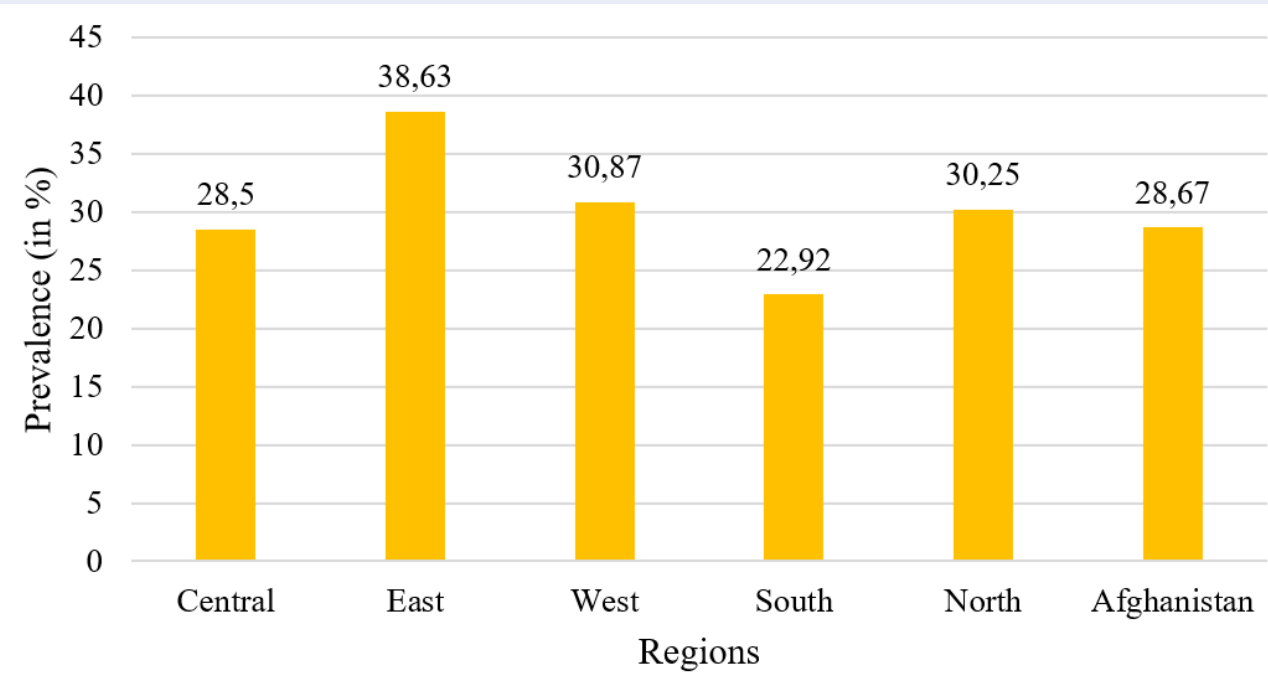

Prevalence of diarrhea

Figure 2: Prevalence of diarrhea by regions in Afghanistan in $2015 .^{a}$

${ }^{a}$ Source: AFDHS-2015

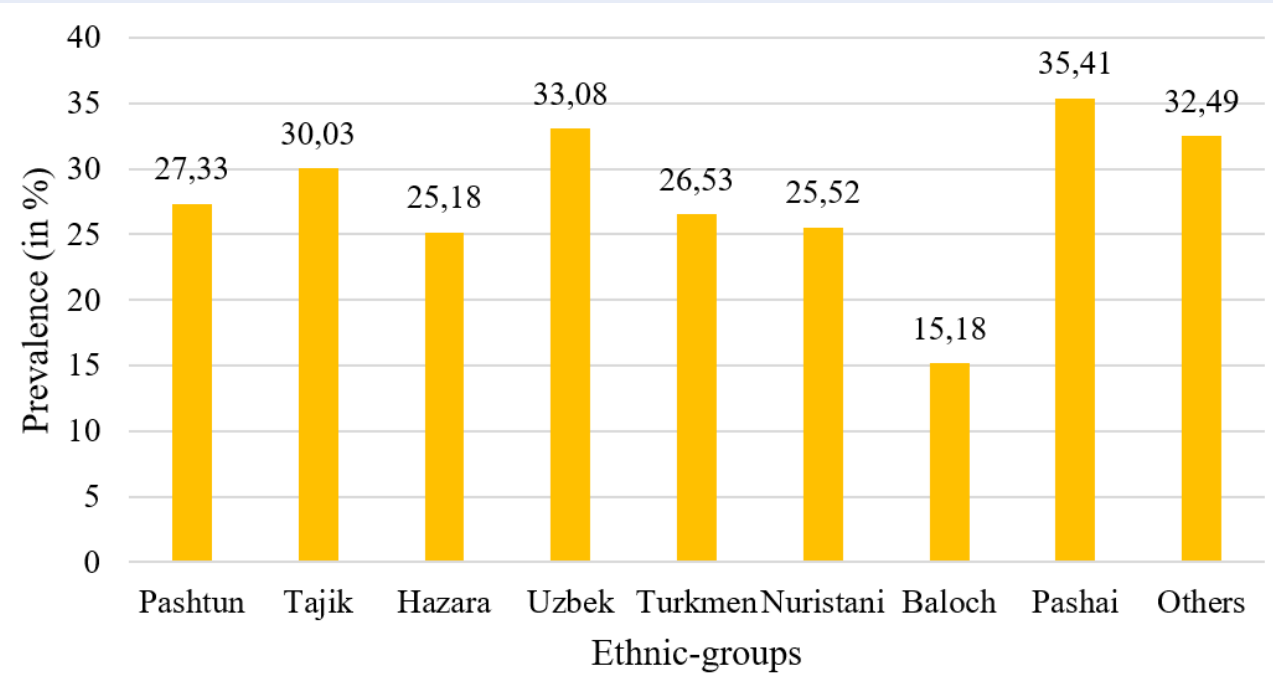

Prevalence of diarrhea

Figure 3: Prevalence of diarrhea by ethnic-groups in Afghanistan in the year 2015.

${ }^{a}$ Source: AFDHS-2015 
Table 1: Prevalence of Diarrhea with Background Characteristics AfDHS-2015

\begin{tabular}{|c|c|c|}
\hline Background characteristics & Prevalence of Diarrhea (\%) & Sample distribution \\
\hline \multicolumn{3}{|l|}{ Child age } \\
\hline$<6$ & 20.83 & 3095 \\
\hline $6-12^{\prime}$ & 34.61 & 2720 \\
\hline $13-24^{\prime}$ & 37.92 & 5708 \\
\hline $25-36^{\prime}$ & 32.16 & 6598 \\
\hline $49+$ & 19.11 & 5902 \\
\hline \multicolumn{3}{|l|}{ Child sex } \\
\hline Male & 29.49 & 15605 \\
\hline Female & 27.8 & 14699 \\
\hline \multicolumn{3}{|l|}{ Birth order } \\
\hline$<2$ & 28.85 & 11159 \\
\hline $3-5$ & 27.86 & 11640 \\
\hline $6+$ & 29.64 & 7505 \\
\hline \multicolumn{3}{|l|}{ Mother's education } \\
\hline Education & 28.47 & 25261 \\
\hline Primary & 32.1 & 2429 \\
\hline Secondary & 29.6 & 2130 \\
\hline Higher & 17.77 & 484 \\
\hline \multicolumn{3}{|l|}{ Mother's working status } \\
\hline No & 28.28 & 26925 \\
\hline Yes & 32.31 & 3244 \\
\hline \multicolumn{3}{|l|}{ Mother's age at first birth } \\
\hline Adolescent Mothers & 29.67 & 17612 \\
\hline Adult Mothers & 27.27 & 12692 \\
\hline \multicolumn{3}{|l|}{ Place of residence } \\
\hline Urban & 32.01 & 7040 \\
\hline Rural & 27.65 & 23264 \\
\hline \multicolumn{3}{|l|}{ Sources of drinking water } \\
\hline Piped water & 25.34 & 1898 \\
\hline Tap water & 30.61 & 4918 \\
\hline Well water & 29.05 & 13716 \\
\hline Unimproved water & 27.8 & 9771 \\
\hline \multicolumn{3}{|l|}{ Time taken to Water } \\
\hline Premises & 27.64 & 13625 \\
\hline Out of Premises & 29.68 & 16393 \\
\hline \multicolumn{3}{|l|}{ Toilet facility } \\
\hline Open Defecated & 30.1 & 4016 \\
\hline Non-Open Defecated & 28.45 & 26288 \\
\hline \multicolumn{3}{|l|}{ Toilet sharing facility } \\
\hline No & 28.08 & 25416 \\
\hline Yes & 31.73 & 4888 \\
\hline \multicolumn{3}{|l|}{ Breast feeding } \\
\hline Never breast feeding & 28.67 & 507 \\
\hline Ever breast feeding & 28.6 & 29797 \\
\hline \multicolumn{3}{|l|}{ Regions } \\
\hline Central & 28.50 & 6021 \\
\hline East & 38.63 & 1742 \\
\hline West & 30.87 & 4426 \\
\hline South & 22.92 & 7470 \\
\hline North & 30.25 & 10646 \\
\hline Afghanistan & 28.67 & 30304 \\
\hline
\end{tabular}

Sources: Authors' calculation from AfDHS-2015. 
Table 2 studies the association of diarrhea and various determinants of sanitation and water and some vital demographic factors. We found that age is closely associated with diarrhea, particularly from 6 to 18 months $(\mathrm{OR}=2.26 \& 2.45 ; \mathrm{p}<0.001)$. Similarly, female children are $6 \%$ less likely to have diarrhea than males $(\mathrm{OR}=0.94 ; \mathrm{p}<0.001)$. Our results showed that children belonging to households defecating in the open are 17 times more likely to have diarrheal diseases than those that do not $(\mathrm{OR}=1.17$; $\mathrm{p}$ $<0.001$ ). Similarly, we can see that children belonging to households sharing toilets are at greater risk of diarrheal diseases $(O R=1.15 ; p<0.001)$. Simultaneously, it has been found that those using tap water are at greater risk of having diarrheal diseases followed by well water $(\mathrm{OR}=1.31 \& 1.24 \mathrm{p}<0.001)$. Similarly, those taking another form of water are also at a greater risk of having any diarrheal diseases with an odds ratio of 1.12 at a $10 \%$ significance level.

\section{DISCUSSION}

Child health is an important issue to be addressed around the globe. Deteriorating child health also has long-run consequences on the health system apart from its socio-economic adversities. Child health is affected by various diseases ranging from diarrhea to acute respiratory infections due to vulnerability and less immune systems of children at an early age than the other population groups ${ }^{37}$. Furthermore, the lack of better access to sanitation and clean water results in children's greater vulnerability at a lower age and puts them at higher risk. It has been found that nearly $90 \%$ of diarrheal deaths occur among children in developing countries ${ }^{38-40}$. Studies show that low-income countries are not just affected by deficient water system but by higher open defecation levels and lack access to adequate drinking water ${ }^{7,41}$.

Afghanistan is one of the most affected regions globally due to conflict, and the health system is one of the poorest. While it is evident that higher rates of diarrhea prevail due to multiple risk factors ranging from socio-demographic to economic factors ${ }^{42,43}$. Nevertheless, our study focused mainly on the aspects related to sanitation and water-hygiene. While examining a few behavioral factors like age, sex of the selected population, we found their impact very much consistent with the earlier studies ${ }^{43-47}$. To address this paper's key purpose, we studied the factors like open defecation, shared toilet facility, access to drinking water, and drinking water sources in Afghanistan. The results showed a significant association between diarrhea with these essential factors. It has been found that piped water supplied to households was a key risk factor with greater odds of affecting Afghanistan's diarrheal diseases. Studies have clearly shown that the sanitation facility has correlated with diarrheal morbidity, incredibly open defecation ${ }^{48-53}$. While examining the linkages between open defecation and diarrhea, our result was consistent with the earlier findings.

Various factors are related to diarrheal diseases, remarkably low domestic sanitation water quality, service level, and hygiene ${ }^{30}$. Afghanistan is one of the world's affected regions globally, both in terms of health standards of living. It has the highest IMR poverty rates and other socio-demographic indicators $^{54,55}$. The diarrheal disease still claims the lives of 26 children each day across the country, accounting for nearly $12 \%$ of deaths in Afghanistan ${ }^{56}$. So, understanding these contextual factors associated with diarrheal diseases in the country is critical. These identified factors have a significant impact due to externality effects and need a particular focus, particularly at the regional level, as indicated by our study. Further studies can be conducted to estimate the burden of these factors on morbidity patterns. Since it is already clear from the above that poor sanitation like open defecation, shared toilet facility, and lack of access to drinking water leave children more susceptible to infections that cause diarrhea.

\section{CONCLUSIONS}

The study tried to examine the linkages between sanitation and diarrhea in Afghanistan based on the DHS survey conducted in 2015. Our study is consistent with many other studies while examining the associations between open defecation and diarrheal diseases. We also found that a lack of water and toilet has a significant impact on children's health. Diarrhea has been closely associated with lack of access to proper drinking water and inadequate sanitation facilities. Thus, to reduce the burden of diarrheal diseases, it is essential to focus on the sanitation facilities apart from providing access to clean and purified water. An inclusive policy approach can enhance health challenges and give positive externalities in terms of public health challenges. Afghanistan needs to focus on bettering sanitation and water hygiene facilities so that the more significant burden of diarrheal diseases can be averted to improve child health.

\section{ABBREVIATIONS}

AfDHS: Afghanistan Demographic and Health Survey

CSO: Central Statistics Organization

OR: Odds Ratio 
Table 2: Association of diarrhea with key contextual factors in Afghanistan-2015

\begin{tabular}{|c|c|c|c|}
\hline \multirow[t]{2}{*}{ Background characteristics } & \multirow[t]{2}{*}{ Odds Ratio } & \multicolumn{2}{|c|}{ Confidence Interval } \\
\hline & & Lower limit & Upper limit \\
\hline \multicolumn{4}{|l|}{ Child age } \\
\hline$<6^{\circ}$ & $2.26^{* * *}$ & 2.00 & 2.56 \\
\hline 6-12' & $2.45^{* * *}$ & 2.20 & 2.73 \\
\hline $13-24^{\prime}$ & $2.05^{* * *}$ & 1.85 & 2.29 \\
\hline $25-36$ & $1.61^{* * *}$ & 1.45 & 1.80 \\
\hline $49+$ & 1.09 & 0.97 & 1.22 \\
\hline \multicolumn{4}{|l|}{ Child sex } \\
\hline \multicolumn{4}{|l|}{ Male } \\
\hline Female & $0.94^{* *}$ & 0.89 & 0.99 \\
\hline \multicolumn{4}{|l|}{ Birth order } \\
\hline \multicolumn{4}{|l|}{$<2^{\circ}$} \\
\hline $3-5^{\prime}$ & 1.03 & 0.97 & 1.10 \\
\hline $6+$ & $1.06^{*}$ & 1.00 & 1.14 \\
\hline \multicolumn{4}{|l|}{ Place of residence } \\
\hline \multicolumn{4}{|l|}{ Rural } \\
\hline Urban & $0.86^{* * *}$ & 0.81 & 0.93 \\
\hline \multicolumn{4}{|l|}{ Sources of drinking water } \\
\hline \multicolumn{4}{|l|}{ Piped water } \\
\hline Tap water & $1.31^{* * *}$ & 1.14 & 1.52 \\
\hline Well water & $1.24^{* * *}$ & 1.09 & 1.42 \\
\hline Unimproved water & $1.12^{*}$ & 0.98 & 1.29 \\
\hline \multicolumn{4}{|l|}{ Time taken to water } \\
\hline \multicolumn{4}{|l|}{ Premises ${ }^{\circ}$} \\
\hline Out of Premises & 1.05 & 0.99 & 1.11 \\
\hline \multicolumn{4}{|l|}{ Toilet facility } \\
\hline \multicolumn{4}{|l|}{ Open Defecated } \\
\hline Non-Open Defecated & $1.17^{* * *}$ & 1.09 & 1.27 \\
\hline \multicolumn{4}{|l|}{ Toilet sharing facility } \\
\hline \multicolumn{4}{|l|}{$\mathrm{No}^{\circ}$} \\
\hline Yes & $1.15^{* * *}$ & 1.07 & 1.25 \\
\hline \multicolumn{4}{|l|}{ Regions } \\
\hline \multicolumn{4}{|l|}{ Central $^{\circ}$} \\
\hline East & $1.72^{* * *}$ & 1.55 & 1.92 \\
\hline West & $1.09^{*}$ & 1.00 & 1.20 \\
\hline South & $0.58^{* * *}$ & 0.54 & 0.63 \\
\hline North & 0.96 & 0.90 & 1.04 \\
\hline
\end{tabular}

Notes: ": reference category; ${ }^{*} \mathrm{p}<0.1 ;{ }^{* *} \mathrm{p}<0.05 ;{ }^{* * *} \mathrm{p}<0.01$; Sources: Authors' calculation from AfDHS- 2015. 
SDG: Sustainable development Goals

UNDP: United Nations Development Programme

UNICEF: United Nations International Children's Emergency Fund

USAID: United States Agency for International Development

WHO: World Health Organization

\section{AUTHORS' CONTRIBUTIONS}

All authors equally contributed in this work. All authors read and approved the final manuscript.

\section{FUNDING}

None

\section{CONFLICT OF INTEREST}

None

\section{ACKNOWLEDGMENT}

None

\section{REFERENCES}

1. United Nations Children's Fund. One is too many: Ending child deaths from pneumona and diarrhoea. (accessed August 31, 2020). 2016;Available from: https: //www.unicef.org/publications/files/UNICEF-PneumoniaDiarrhoea-report-2016-web-version5.pdf.

2. Rudan I, Nair H, Marušić A, Campbell H. Reducing mortality from childhood pneumonia and diarrhoea: The leading priority is also the greatest opportunity. J Glob Health. 2013;3:010101. Available from: https://doi.org/10.7189/jogh. 03.010101.

3. World Health Organization. Diarrhoeal disease, Key Facts. (accessed August 31, 2020). 2017;Available from: https://www. who.int/news-room/fact-sheets/detail/diarrhoeal-disease.

4. Mokomane M, Kasvosve I, de Melo E, Pernica JM, Goldfarb DM. The global problem of childhood diarrhoeal diseases: emerging strategies in prevention and management. Ther Adv Infect Dis. 2018;5:29-43. Available from: https://doi.org/10.1177/ 2049936117744429.

5. UNICEF, WHO, World Bank, UN-DESA Population Division, Levels and trends in child mortality 2015 (accessed August 31, 2020). 2015;Available from: https://www.who.int/maternal_child_adolescent/documents/ levels_trends_child_mortality_2015/en/.

6. World Health Organization, World health statistics 2011, World Health Organization, Geneva, Switzerland. (accessed August 31, 2020). 2011;Available from: https://www.who.int/ whosis/whostat/EN_WHS2011_Full.pdf?ua=1.

7. Prüss A, Kay D, Fewtrell L, Bartram J. Estimating the burden of disease from water, sanitation, and hygiene at a global level, Environ. Health Perspect. 2002;110:537. Available from: https: //doi.org/10.1289/ehp.110-1240845.

8. Roushdy R, Sieverding M, Radwan $H$. The impact of water supply and sanitation on child health: Evidence from Egypt. Population Council. 2012;Available from: https://doi.org/10. 31899/pgy3.1016.

9. Boschi-Pinto C. Estimating child mortality due to diarrhoea in developing countries. Bull World Health Organ. 2008;86:710717. Available from: https://doi.org/10.2471/BLT.07.050054.

10. Lamberti LM, Walker CLF, Black RE. Erratum to: Systematic review of diarrhea duration and severity in children and adults in low- and middle-income countries. BMC Public Health. 2012;12:832. Available from: https://doi.org/10.1186/14712458-12-832.
11. Lanata CF, et al. For the Child Health Epidemiology Reference Group of the World Health Organization and UNICEF, Global Causes of Diarrheal Disease Mortality in Children $<5$ Years of Age: A Systematic Review. PLoS ONE. 2013;8:e72788. Available from: https://doi.org/10.1371/journal.pone.0072788.

12. Nataro JP, et al. Diarrhea Among Children in Developing Countries. in N Curtis, A Finn, AJ Pollard (Eds), Hot Topics in Infection and Immunity in Children IX, Springer New York, New York, NY. 2013;p. 73-80. Available from: https://doi.org/ 10.1007/978-1-4614-4726-9_5.

13. World Gastroenterology Organisation. Acute diarrhea in adults and children: a global perspective, World Gastroenterology Organisation. (accessed August 31, 2020). 2012;Available from: https://www.nghd.pt/uploads/acute_ diarrhea.pdf.

14. Central Statistics Organization (CSO). Ministry of Public Health (MoPH), ICF, Afghanistan Demographic and Health Survey 2015, Central Statistics Organization, Kabul, Afghanistan. (accessed August 31, 2020). 2017;Available from: https:// dhsprogram.com/pubs/pdf/FR323/FR323.pdf.

15. Fewtrell $\mathrm{L}$, et al. Water, sanitation, and hygiene interventions to reduce diarrhoea in less developed countries: a systematic review and meta-analysis. The Lancet Infectious Diseases. 2005;5:42-52. Available from: https://doi.org/10.1016/S14733099(04)01253-8.

16. Akseer $\mathrm{N}$, et al. Achieving maternal and child health gains in Afghanistan: a Countdown to 2015 country case study. The Lancet Global Health;4(2016):e395-e413. Available from: https://doi.org/10.1016/S2214-109X(16)30002-X.

17. Divya $S$, et al. A study on selected behavioral factors of mothers influencing acute diarrhoea in under- five children in a rural part of Kerala, India. Int J Community Med Public Health. 2016;2211(2216). Available from: https://doi.org/10.18203/ 2394-6040.ijcmph20162572.

18. Tarekegn M, Enquselassie F. A case control study on determinants of diarrheal morbidity among under-five children in Wolaita Soddo Town, Southern Ethiopia. (accessed August 31, 2020). Ethiopian Journal of Health Development . 2012;26. Available from: https://www.ajol.info/index.php/ejhd/article/ view/115024.

19. Dessalegn M, Kumie A, Tefera W. Predictors of under-five childhood diarrhea: Mecha District, West Gojam, Ethiopia. (accessed August 31, 2020). Ethiopian Journal of Health Development. 2011;25. Available from: https://www.ajol.info/index. php/ejhd/article/view/83811.

20. Mock NB, Sellers TA, Abdoh AA, Franklin RR. Socioeconomic environmental, demographic and behavioral factors associated with occurrence of diarrhea in young children in the Republic of Congo. Social Science \& Medicine. 1993;36:807-816 Available from: https://doi.org/10.1016/0277-9536(93)90041-

21. Mbugua S, Musikoyo E, Ndungi F, Sang R, Kamau-Mbuthia E, Ngotho $D$. Determinants of diarrhea among young children under the age of five in Kenya, evidence from KDHS 2008-09. APS. 2014;28:1046. Available from: https://doi.org/10.11564/ 28-0-556.

22. Vásquez WF, Aksan AM. Water, sanitation, and diarrhea incidence among children: evidence from Guatemala. Water Policy. 2015;17:932-945. Available from: https://doi.org/10.2166/ wp.2015.211.

23. UNICEF. Organización Mundial de la Salud, Diarrhoea: why children are still dying and what can be done. United Nations Children's Fund, New York. 2009;.

24. Adane M, Mengistie B, Kloos H, Medhin G, Mulat W. Sanitation facilities, hygienic conditions, and prevalence of acute diarrhea among under-five children in slums of Addis Ababa, Ethiopia: Baseline survey of a longitudinal study. PLoS ONE. 2017;12:e0182783. Available from: https://doi.org/10.1371/ journal.pone.0182783.

25. Anteneh A, Kumie A. Assessment of the impact of latrine utilization on diarrhoeal diseases in the rural community of 
Hulet Ejju Enessie Woreda, East Gojjam Zone, Amhara Region. Ethiopian Journal of Health Development. 2010;24. Available from: https://doi.org/10.4314/ejhd.v24i2.62959.

26. Keusch GT, Fontaine O, et al. Disease Control Priorities in Developing Countries, 2nd ed. (accessed August 31, 2020). World Bank, Washington (DC). 2006;Available from: http:// www.ncbi.nlm.nih.gov/books/NBK11764/.

27. Yaya S, et al. Improving Water, Sanitation and Hygiene Practices, and Housing Quality to Prevent Diarrhea among UnderFive Children in Nigeria. TropicalMed. 2018;3:41. Available from: https://doi.org/10.3390/tropicalmed3020041.

28. World Health Organization. UN-water global annual assessment of sanitation and drinking-water: 2008 pilot report : testing a new reporting approach. (accessed August 31, 2020). World Health Organization, Geneva. 2008;Available from: https://apps.who.int/iris/handle/10665/43977.

29. Oyekale A. Access to safe drinking water, sanitation, and under 5 diarrhea morbidity in South Africa. Ann Trop Med Public Health. 2017;10:187. Available from: https://doi.org/10.4103/ 1755-6783.205585.

30. World Health Organization. The World Health Report 2005 make every mother and child count, Geneva. 2005;.

31. John TJ, Samuel R. Herd immunity and herd effect: new insights and definitions. European Journal of Epidemiology. 2000;16:601-606. Available from: https://doi.org/10.1023/A: 1007626510002.

32. Mara D, Lane J, Scott B, Trouba D. Sanitation and Health. PLoS Med. 2010;7:e1000363. Available from: https://doi.org/ 10.1371/journal.pmed.1000363.

33. Newson RS, Lion $R$, et al. Behaviour change for better health: nutrition, hygiene and sustainability. BMC Public Health. 2013;13:S1. Available from: https://doi.org/10.1186/14712458-13-S1-S1.

34. USAID. Wash \& nutrition water and development strategy implementation brief. (accessed August 31, 2020). 2015;Available from: https://2012-2017.usaid.gov/sites/default/files/ documents/1865/WASH_Nutrition_Implementation_Brief_ Jan_2015.pdf.

35. Semba RD, et al. Relationship of the presence of a household improved latrine with diarrhea and under-five child mortality in Indonesia. Am J Trop Med Hyg. 2011;84:443-450. Available from: https://doi.org/10.4269/ajtmh.2011.10-0244.

36. Spears D, Ghosh A, Cumming O. Open Defecation and Childhood Stunting in India: An Ecological Analysis of New Data from 112 Districts. PLoS ONE. 2013;8:e73784. Available from: https://doi.org/10.1371/journal.pone.0073784.

37. Mintz E, Bartram J, Lochery P, Wegelin M. Not Just a Drop in the Bucket: Expanding Access to Point-of-Use Water Treatment Systems. Am J Public Health. 2001;91:1565-1570. Available from: https://doi.org/10.2105/AJPH.91.10.1565.

38. Bitew BD, Woldu W, Gizaw Z. Childhood diarrheal morbidity and sanitation predictors in a nomadic community. Ital J Pediatr. 2017;43:91. Available from: https://doi.org/10.1186/ s13052-017-0412-6.

39. Lakshminarayanan $\mathrm{S}$, Jayalakshmy R. Diarrheal diseases among children in India: Current scenario and future perspectives. J Nat Sc Biol Med. 2015;6:24. Available from: https: //doi.org/10.4103/0976-9668.149073.

40. Wardlaw T, Salama P, Brocklehurst C, Chopra M, Mason E. Diarrhoea: why children are still dying and what can be done. The Lancet. 2010;375:870-872. Available from: https://doi.org/10. 1016/S0140-6736(09)61798-0.

41. World Health Organization. United Nations Children's Fund, Progress on sanitation and drinking-water: Joint Monitoring Programme 2010 update, World Health Organization, Geneva. (accessed August 31, 2020). 2010;Available from: https://www.who.int/water_sanitation_health/publications/ 9789241563956/en/.

42. Ahiadeke C. Breast-feeding, diarrhoea and sanitation as components of infant and child health: a study of large scale sur- vey data from Ghana and Nigeria. J Biosoc Sci. 2000;32:47-61. Available from: https://doi.org/10.1017/S002193200000047X.

43. Boadi KO, Kuitunen M. Environmental and health impacts of household solid waste handling and disposal practices in third world cities: the case of the Accra Metropolitan Area, Ghana. J Environ Health. 2005;68:32-36.

44. Arif GM, Ibrahim S. Diarrhoea Morbidity Differentials among Children in Pakistan. (accessed August 31, 2020). The Pakistan Development Review. 1998;37. Available from: https://www. pide.org.pk/pdf/PDR/1998/Volume3/205-230.pdf.

45. Janovsky K. World Health Organization, The challenge of implementation : district health systems for primary health care, World Health Organization. (accessed August 31, 2020). https://appswhoint/iris/handle/10665/62369. 1988;

46. Thea DM, et al. A prospective study of diarrhea and HIV1 infection among 429 Zairian infants. N Engl J Med. 1993;329:1696-1702. Available from: https://doi.org/10.1056/ NEJM199312023292304.

47. VanDerslice J, Briscoe J. Environmental interventions in developing countries: interactions and their implications. Am J Epidemiol. 1995;141:135-144. Available from: https://doi.org/ 10.1093/oxfordjournals.aje.a117401.

48. Desai R, McFarlane C, Graham S. The Politics of Open Defecation: Informality, Body, and Infrastructure in Mumbai: The Politics of Open Defecation: Mumbai. Antipode. 2015;47:98120. Available from: https://doi.org/10.1111/anti.12117.

49. Montgomery MA, Elimelech M. Water and sanitation in developing countries: including health in the equation. Environ Sci Technol. 2007;41:17-24. Available from: https://doi.org/10 1021/es072435t.

50. Njuguna J. Effect of eliminating open defecation on diarrhoeal morbidity: an ecological study of Namable sub-county, Kenya. (accessed August 31, 2020). in: WEDC, Loughborough University, UK. 2015;Available from: https://repository.lboro.ac.uk/articles/Effect_of_eliminating_ open_defecation_on_diarrhoeal_morbidity_an_ecological_ study_of_Namable_sub-county_Kenya/9587009.

51. Pickering AJ, Djebbari H, Lopez C, Coulibaly M, Alzua ML. Effect of a community-led sanitation intervention on child diarrhoea and child growth in rural Mali: a cluster-randomised controlled trial. The Lancet Global Health. 2015;3:e701e711. Available from: https://doi.org/10.1016/S2214-109X(15) 00144-8.

52. United Nations Office for the Coordination of Humanitarian Affairs (OCHA). Malnutrition: the silent killer in Afghanistan. (accessed August 31, 2020). 2016;Available from: https://www.humanitarianresponse.info/sites/ www.humanitarianresponse.info/files/documents/files/afg_monthly_humanitarian_bulletin_july_2016_0.pdf.

53. World Health Organization. Preventing diarrhoea through better water, sanitaiton and hygiene: exposures and impacts in low- and middle-income countries. 2014;

54. Higgins-Steele A, Yousufi K, Sultana S, Ali AS, Varkey S. Ending Preventable Child Deaths from Pneumonia and Diarrhoea in Afghanistan: An Analysis of Intervention Coverage Scenarios Using the Lives Saved Tool. J Trop Med. 2017;2017:3120854. Available from: https://doi.org/10.1155/2017/3120854.

55. The United Nations Development Programme (UNDP). Human Development Report 2015 - Work for Human Development. (accessed August 31, 2020). 2015;Available from: https://www.in.undp.org/content/india/en/home/library/hdr/ human-development-products/GHDR-2015.html.

56. World Health Organization (WHO. United Nations Children's Fund (UNICEF), Progress on Drinking Water, Sanitation and Hygiene: 2017 Update and SDG Baselines., World Health Organization, Geneva, Switzerland. (accessed August 31, 2020). 2017; Available from: https://www.unicef.org/publications/files/Progress_on_ Drinking_Water_Sanitation_and_Hygiene_2017.pdf. 